・生物编目・

\title{
中国石松类和烣类植物的多样性与地理分布
}

\author{
周喜乐 ${ }^{1}$ 张宪春 $^{2}$ 孙久琼 $^{2}$ 严岳鸿 $^{1 *}$ \\ 1 (上海辰山植物园, 中国科学院上海辰山植物科学研究中心, 上海 201602) \\ 2 (中国科学院植物研究所系统与进化植物学国家重点实验室, 北京 100093)
}

\begin{abstract}
摘要: 物种编目及其科属系统排列是了解生物多样性的基础, 本文采用Flora of China使用的分类系统, 结合最新 分子分类学研究成果以及近几年发表的新资料, 对中国石松类和锁类植物多样性和地理分布数据进行了统计和分 析。结果表明中国共有石松类和藓类植物 40 科 178 属 2,147 种 5 个亚种 118 个变种, 其中特有种 839 个, 占总种数的 $39.08 \%$ 。种数最多的 5 个科依次为鳞毛茨科(505种, 含种下单位, 下同)、蹄盖茨科(323种)、水龙骨科(280种)、风

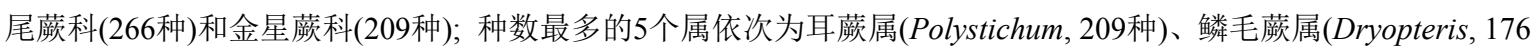

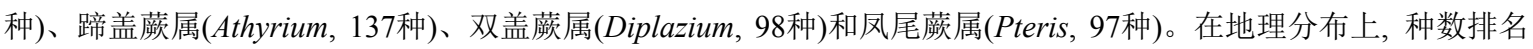
前 5 的省份为云南 $(1,365$ 种)、四川(875种)、贵州(838种)、广西(785种)和台湾(779种)。含中国特有石松类和荻类植

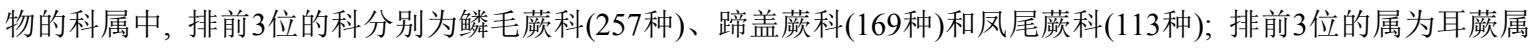
(140种)、蹄盖偋属(82种)和鳞毛蒴属(61种)。
\end{abstract}

关键词: 植物分类学; 保护生物地理学; 生物多样性; 保护生物学; 蒴类植物

\section{Diversity and distribution of lycophytes and ferns in China}

Xile Zhou ${ }^{1}$, Xianchun Zhang ${ }^{2}$, Jiuqiong Sun ${ }^{2}$, Yuehong Yan $^{1 *}$

1 Shanghai Chenshan Botanical Garden, Shanghai Chenshan Plant Science Research Center, Chinese Academy of Sciences, Shanghai 201602

2 State Key Laboratory of Systematic and Evolutionary Botany, Institute of Botany, Chinese Academy of Sciences, Beijing 100093

\begin{abstract}
The species catalogue and phylogenetic arrangement are the basis of species diversity studies. We collated the latest lycophytes and ferns in China found in recent years using the system from Flora of China. There are 2,147 species, 5 subspecies, 118 varieties, 178 genera and 40 families of lycophytes and ferns in China, including 839 endemic species, which accounts for $39.08 \%$ of total species. The top five families are Dryopteridaceae (505 species, including subspecies and varieties), Athyriaceae (323 species), Polypodiaceae (280 species), Pteridaceae (266 species) and Thelypteridaceae (209 species). The top five genera are Polystichum (209 species), Dryopteris (176 species), Athyrium (137 species), Diplazium (98 species) and Pteris (97 species). The following five provinces are rich in lycophytes and ferns: Yunnan (1,365 species), Sichuan (875 species), Guizhou (838 species), Guangxi (785 species) and Taiwan (779 species). Endemic species are rich in families including Dryopteridaceae (257 species), Athyriaceae (169 species), and Pteridaceae (113 species) and genera of Polystichum (140 species), Athyrium (82 species), and Dryopteris (61 species).
\end{abstract}

Key words: plant taxonomy; conservation biogeography; biodiversity; conservation biology; pteridophytes

传统的分类方法将现代蕨类植物 (pteridophytes)分为 5 个亚门: 松叶偋亚门(Psilophytina)、石松亚
门(Lycophytina)、水韭亚门(Isoëphytina)、楔叶蕨亚 门(Sphenophytina)和真䓲亚门(Filicophytina) (秦仁

收稿日期: 2015-09-18; 接受日期: 2015-12-29

基金项目: 科技部基础性工作专项(2015FY110200)

* 通迅作者 Author for correspondence. E-mail: yhyan@sibs.ac.cn 
昌，1978a，b)，其中前 4 个亚门称为拟蕨类植物

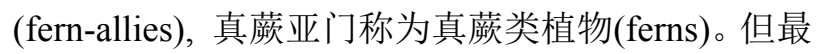
新的研究又将现代䕬类植物分为两个大类: 石松类 (lycophytes)和葓类(ferns) (Pryer et al, 2001; Smith et al，2006), 其中石松类包括了石松科 (Lycopodiaceae)、水非科(Isoëtaceae)和卷柏科 (Selaginellaceae), 其他类群都称为䓲类植物(Christenhusz et al, 2011)。

石松类和蒝类植物全世界现存约 12,000种 (Chapman, 2009), 隶属50个科，260-280个属 (Christenhusz et al, 2011; Christenhusz \& Schneider, 2011)。由于分类的复杂性, 中国石松类和蒝类植物 的科属种数目一直在变动, 如秦仁昌1978年的分类 系统中收录了63科223属(秦仁昌, 1978a, b); 吴兆洪 和秦仁昌编写的《中国䕬类植物科属志》收录有 63 科226属(吴兆洪和秦仁昌, 1991); 《中国植物志》采 用秦仁昌 1978 年的分类系统, 将碗硕科 (Dennstaedtiaceae) 并入姬偋科(Hypolepidaceae), 竹 叶硕科(Taenitidaceae)并入鳞始硕科(Lindsaeaceae), 实际记载 63 科 220 属 2,539 种 8 亚种 158 变种 33 变型和 4 个杂种(《中国植物志》编辑委员会，1959-2000); 严岳鸿等(2013)基于秦仁昌1978年的分类系统, 在 《中国偋类植物多样性与地理分布》一书中收录63 科221属2,452种(包含亚种、变种和变型)。张宪春 (2012)在《中国石松类和䓲类植物》一书中采用最 新的分子分类系统, 认为中国分布有 38 科 164 属约 2,300种 (含种下分类群及杂交类群); 随后, 张宪春 等(2013)又在其2012年的科属分类基础上增加了 1 个未正式发表的爬树蕨科(Arthropteridaceae), 并调 整了部分属的范畴, 认为中国石松类和蕨类植物有 39 科140余属及 15 个分类不确定属。Flora of China 记载了石松类和蕨类38科177属2,258种(包含127个 亚种和变种) (Wu et al, 2013)。综上所述, 从传统的 形态学为代表的秦仁昌系统来看, 中国石松类和偋 类植物共有 63个科, 220-226个属; 从现代分子系统 学来看, 中国石松类和蕨类植物共有 39 科, 约 140-177属。

本文根据最新的研究成果, 以现代分子系统学 成果为分类依据, 统计中国石松类和蕨类植物科属 种数目, 分析中国石松类和蒝类植物多样性与地理 分布的特点。

\section{1 方法}

本文以 《中国植物志》和Flora of China (Wu et $\mathrm{al}, 2013)$ 为依据, 结合近几年发表的蒝类新资料 (Liu et al, 2013; Shrestha et al, 2014; Shrestha \& Zhang, 2015a, b; 谭运洪等, 2015; Zhang \& Zhang, 2015), 采用Flora of China使用的分子分类系统, 统 计中国石松类和蕨类植物的科属组成和物种数目, 各省(市、自治区)石松类、蕨类植物多样性和特有 性以及中国石松类和蕨类植物科属中的特有种。

\section{2 结果}

经统计分析, 确定中国共有石松类和偋类植物 40 科178属2,147种, 5 个亚种, 118 个变种, 总计 2,270 个分类群。其中栽培种 5 个, 即小翠云 (Selaginella kraussiana)、细叶满江红(Azolla filiculoides)、勺叶 槐叶蘋(Salvinia cuculata)、人庆槐叶蘋(S. molesta) 和圆叶肾偋(Nephrolepis duffii); 特有种 839 个(不含 76 个特有亚种和变种), 占总种数的 $39.08 \%$ 。

\section{1 中国石松类和斴类植物的科属组成 \\ 2.1.1 科的组成}

Flora of China采用最新分子系统学研究结果, 记载有中国石松类和痥类植物 38 科。本文根据最新 的资料, 增加了爬树蕨科(Liu et al, 2013)和翼盖蕨 科(Didymochlaenaceae) (谭运洪等, 2015; Zhang \& Zhang, 2015), 总科数达到 40 个。其中鳞毛疹科 (Dryopteridaceae) 种数最多, 有 505 种(除特别说明 外, 下文的种均包含种下), 占总种数的 $22.25 \%$ 。另 有 4 个达到 200 种以上的科, 分别为蹄盖蒝科 (Athyriaceae, 323种)、水龙骨科(Polypodiaceae, 280 种)、凤尾蒝科(Pteridaceae, 266 种) 和金星蒝科 (Thelypteridaceae, 209种), 这五个科包含了93 属 1,583 种, 占总属数的 $52.25 \%$, 总种数的 $69.74 \%$ 。种 数 10 种以上的科有 22 个, 占总科数的 $55 \%$, 包含了 153 属 2,191 种, 占总属数的 $86.44 \%$, 总种数的 $96.52 \%$ 。仅含 1 个属的科有 15 个, 占总科数的 $37.5 \%$, 比例较高; 仅含 1 个种的科有 2 个, 分别是松叶䓲科 (Psilotaceae)和翼盖硕科(附录1)。

\subsection{2 属的组成}

Flora of China中记载了中国蕨类植物177属。 本文根据最新文献, 将光叶蒴属(Cystoathyrium) 并 入冷硕属(Cystopteris) (Wei \& Zhang, 2014); 将四川 
表1 中国各省(市、自治区)石松类和蕨类植物多样性及特有种统计

Table 1 The diversity and endemism of lycophytes and ferns in each province of China

\begin{tabular}{|c|c|c|c|c|c|c|c|c|}
\hline $\begin{array}{l}\text { 省(市、自治区) } \\
\text { Province }\end{array}$ & $\begin{array}{l}\text { 种 } \\
\text { Species }\end{array}$ & $\begin{array}{l}\text { 属 } \\
\text { Genus }\end{array}$ & $\begin{array}{l}\text { 科 } \\
\text { Family }\end{array}$ & $\begin{array}{l}\text { 中国特有种 } \\
\text { Number of } \\
\text { Chinese } \\
\text { endemic } \\
\text { species } \\
\text { (CES) }\end{array}$ & $\begin{array}{l}\text { 占本地区种数 } \\
\text { 比例 } \\
\text { Ratio of CES } \\
\text { in each prov- } \\
\text { ince }\end{array}$ & $\begin{array}{l}\text { 仅产本地区 } \\
\text { Number of } \\
\text { local en- } \\
\text { demic spe- } \\
\text { cies (LES) }\end{array}$ & $\begin{array}{l}\text { 占本地区中 } \\
\text { 国特有种比 } \\
\text { 例 } \\
\text { Ratio of } \\
\text { LES/CES }\end{array}$ & $\begin{array}{l}\text { 国内仅产本地区且 } \\
\text { 国外有分布 } \\
\text { Number of species } \\
\text { distrbute only in this } \\
\text { province and abroad }\end{array}$ \\
\hline 云南 Yunnan & $1,365(60.13 \%)$ & $148(83.15 \%)$ & $40(100.00 \%)$ & 414 & 30.33 & 181 & 43.72 & 77 \\
\hline 四川 Sichuan & $875(38.55 \%)$ & $116(65.17 \%)$ & $36(90.00 \%)$ & 284 & 32.46 & 54 & 19.01 & 1 \\
\hline 贵州 Guizhou & $838(36.92 \%)$ & $119(66.85 \%)$ & $36(90.00 \%)$ & 227 & 27.09 & 31 & 13.66 & 1 \\
\hline 广西 Guangxi & 785 (34.58\%) & $125(70.22 \%)$ & $36(90.00 \%)$ & 157 & 20.00 & 23 & 14.65 & 5 \\
\hline 台湾 Taiwan & $779(34.32 \%)$ & $145(81.46 \%)$ & $39(97.50 \%)$ & 107 & 13.74 & 59 & 55.14 & 89 \\
\hline 湖南 Hunan & $663(29.20 \%)$ & $110(61.80 \%)$ & $35(87.50 \%)$ & 180 & 27.15 & 6 & 3.33 & 0 \\
\hline 西藏 Tibet & $579(25.51 \%)$ & $104(58.43 \%)$ & $33(82.50 \%)$ & 121 & 20.90 & 49 & 40.50 & 14 \\
\hline 广东 Guangdong & $566(24.93 \%)$ & $117(65.73 \%)$ & $32(80.00 \%)$ & 95 & 16.78 & 9 & 9.47 & 2 \\
\hline 重庆 Chongqing & $535(23.57 \%)$ & $93(52.25 \%)$ & $33(82.50 \%)$ & 154 & 28.79 & 9 & 5.84 & 0 \\
\hline 海南 Hainan & $451(19.87 \%)$ & $113(63.48 \%)$ & $33(82.50 \%)$ & 62 & 13.75 & 33 & 53.23 & 19 \\
\hline 江西 Jiangxi & $442(19.47 \%)$ & $96(53.93 \%)$ & $33(82.50 \%)$ & 85 & 19.23 & 2 & 2.35 & 0 \\
\hline 浙江 Zhejiang & 431 (18.99\%) & $98(55.06 \%)$ & $35(87.50 \%)$ & 88 & 20.42 & 7 & 7.95 & 3 \\
\hline 福建 Fujian & $409(18.02 \%)$ & $100(56.18 \%)$ & $31(77.50 \%)$ & 67 & 16.38 & 4 & 5.97 & 1 \\
\hline 湖北 Hubei & $372(16.39 \%)$ & $80(44.94 \%)$ & $29(72.50 \%)$ & 102 & 27.42 & 5 & 4.90 & 0 \\
\hline 甘肃 Gansu & $254(11.19 \%)$ & $64(35.96 \%)$ & $25(62.50 \%)$ & 65 & 25.59 & 3 & 4.62 & 0 \\
\hline 安徽 Anhui & $237(10.44 \%)$ & $69(38.76 \%)$ & $26(65.00 \%)$ & 39 & 16.46 & 0 & 0.00 & 1 \\
\hline 陕西 Shaanxi & $231(10.18 \%)$ & $56(31.46 \%)$ & $22(55.00 \%)$ & 62 & 26.84 & 0 & 0.00 & 0 \\
\hline 河南 Henan & $218(9.60 \%)$ & $62(34.83 \%)$ & $25(62.50 \%)$ & 46 & 21.10 & 1 & 2.17 & 0 \\
\hline 香港 Hongkong & $212(9.34 \%)$ & $77(43.26 \%)$ & $29(72.50 \%)$ & 16 & 7.55 & 0 & 0.00 & 0 \\
\hline 江苏 Jiangsu & $151(6.65 \%)$ & $59(33.15 \%)$ & $26(65.00 \%)$ & 18 & 11.92 & 0 & 0.00 & 0 \\
\hline 河北 Hebei & $112(4.93 \%)$ & $39(21.91 \%)$ & $18(45.00 \%)$ & 26 & 23.21 & 0 & 0.00 & 0 \\
\hline 辽宁 Liaoning & $110(4.85 \%)$ & $41(23.03 \%)$ & $19(47.50 \%)$ & 10 & 9.09 & 0 & 0.00 & 2 \\
\hline 吉林 Jilin & $107(4.71 \%)$ & $38(21.35 \%)$ & $17(42.50 \%)$ & 6 & 5.61 & 2 & 33.33 & 1 \\
\hline 山西 Shanxi & $99(4.36 \%)$ & $35(19.66 \%)$ & $17(42.50 \%)$ & 24 & 24.24 & 0 & 0.00 & 0 \\
\hline 山东 Shandong & $97(4.27 \%)$ & $38(21.35 \%)$ & $19(47.50 \%)$ & 19 & 19.59 & 2 & 10.53 & 0 \\
\hline 黑龙江 Heilongjiang & $89(3.92 \%)$ & $34(19.10 \%)$ & $17(42.50 \%)$ & 4 & 4.49 & 1 & 25.00 & 3 \\
\hline 澳门 Macao & $76(3.35 \%)$ & $46(25.84 \%)$ & $24(60.00 \%)$ & 2 & 2.63 & 0 & 0.00 & 0 \\
\hline $\begin{array}{l}\text { 内蒙古 Inner Mon- } \\
\text { golia }\end{array}$ & $72(3.17 \%)$ & $25(14.04 \%)$ & $15(37.50 \%)$ & 11 & 15.28 & 0 & 0.00 & 0 \\
\hline 北京 Beijing & $71(3.13 \%)$ & $27(15.17 \%)$ & $17(42.50 \%)$ & 15 & 21.13 & 0 & 0.00 & 0 \\
\hline 新疆 Xinjiang & $57(2.51 \%)$ & $22(12.36 \%)$ & $14(35.00 \%)$ & 3 & 5.26 & 0 & 0.00 & 6 \\
\hline 青海 Qinghai & $52(2.29 \%)$ & $20(11.24 \%)$ & $13(32.50 \%)$ & 11 & 21.15 & 0 & 0.00 & 0 \\
\hline 上海 Shanghai & $51(2.25 \%)$ & $31(17.42 \%)$ & $17(42.50 \%)$ & 2 & 3.92 & 0 & 0.00 & 0 \\
\hline 宁夏 Ningxia & $40(1.76 \%)$ & $19(10.67 \%)$ & $12(30.00 \%)$ & 7 & 17.50 & 0 & 0.00 & 0 \\
\hline 天津 Tianjin & $29(1.28 \%)$ & $15(8.43 \%)$ & $12(30.00 \%)$ & 5 & 17.24 & 0 & 0.00 & 0 \\
\hline
\end{tabular}

旱硕(Pellaea connectens)从旱硕属(Pellaea)中分出, 归入钝旱蕨属(Argyrochosma) (Wang et al, 2015); 同 时新增了翼盖蕨属(Didymochlaena) (翼囊硕属) (谭 运洪等, 2015), 因此本文最终统计结果为178属。种 数最多的属为耳敎属(Polystichum), 有 209 种, 占总
种数的 $9.21 \%$ 。包含 100 种以上的属还有鳞毛蕨属 (Dryopteris，176种)和蹄盖蕨属(Athyrium，137种), 分别占总种数的 $7.75 \%$ 和 $6.04 \%$ 。这三属共包含了 522 种, 占总种数的 $23.00 \%$ 。20种以上的属有 27 个, 占总属数的 $15.17 \%$ 。该 27 属包含了 1,574 种，占总种 
数的 $69.34 \%$ 。仅含 1 个种的属有 46 个, 占总属数的 $25.84 \%$, 可见单种属的属也占有较高比例(附录2)。

\section{2 中国石松类和蒴类植物的地理分布}

\subsection{1 各省(市、自治区)石松类和蕨类植物多样性}

经统计, 中国 34 个省(市、自治区)中, 石松类和

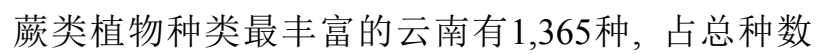
的 $60.13 \%$; 有 148 个属, 占总属数的 $83.15 \%$; 涵盖 了中国所有的科。排名第二的四川省有 875 种。排 名第三至第五的分别为贵州(838种)、广西(785种) 和台湾(779种)。属数达到110属的省份有台湾(145 属)、广西(125属)、贵州(119属)、广东(117属)、四 川(116属)、海南(113属)和湖南(110属) (表1)。

\subsection{2 各省(市、自治区)石松类和烣类植物的特有性}

在各省(市、自治区)特有蕨类中(表1), 云南有 中国特有种 414 个, 占云南蒝类植物总数的 $30.33 \%$, 其中有 181 种仅产云南本省, 占云南中国特有种的 $43.72 \%$ 。包含 150 种以上中国特有种的省份还有四 川(284种)、贵州(227种)、湖南(180种)、广西(157 种)和重庆(154种), 其中仅产本省的特有种数量分 别为四川 54 种、贵州 31 种、湖南6种、广西 23 种和 重庆9种。而台湾、西藏和海南的中国特有种虽然 数量排在第六之后(分别为 $107 、 121$ 和 62 种), 但其省 内特有种数量却很高, 分别达到59、49和33种, 仅 低于云南的 181 种和四川的 54 种, 占本省中国特有 种的比例分别为 $55.14 \% 、 40.50 \%$ 和 $53.23 \%$, 该比例 达到 $40 \%$ 以上的还有云南 $(43.72 \%)$, 远远高于其他 省(市、自治区)。

另外, 有 89 个物种在中国仅分布在台湾, 77 个 物种在中国仅分布在云南。类似的还有海南19种, 西藏14种, 新疆 6 种, 广西 5 种, 浙江和黑龙江各 3 种, 广东和辽宁 2 种, 四川、贵州、福建、安徽和吉 林各 1 种。

\section{3 中国特有石松类和斴类植物}

\subsection{1 科中特有种的分布}

中国石松类和䓲类植物共有特有种 915 个(其中 76 个为特有亚种和变种)。在中国 40 个科中, 有 29 个 科中存在特有种, 其中鳞毛蒌科中特有种最多, 达 到 257 个, 占该科种数的 $50.89 \%$, 占中国特有种总 数的 $28.09 \%$ 。其他特有种数达到 100 种的科还有蹄 盖媭科(169种)、凤尾葓科(113种)和金星蒴科(107 种)。特有种在科中比例达到 $50 \%$ 的科还有水非科 $(100 \%) 、$ 肿足偋科(Hypodematiaceae, $61.54 \%)$ 、轴果
蕨科 (Rhachidosoraceae, $60.00 \%$ ) 、合囊䓲科

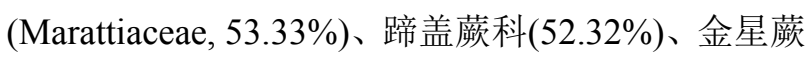
科(51.20\%)和爬树偋科(50.00\%) (附录3)。

\subsection{2 属中特有种的分布}

中国178个属中, 93属中有特有种, 其中扇蒴属 (Neocheiropteris) 和边果偋属(Craspedosorus) 为中国 特有属。特有种最多的是耳蒝属, 达到 140 个, 远远 超过其他属，占该科总种数的 $27.72 \%$, 占该科特有 种的 $54.47 \%$, 占该属总种数的 $66.99 \%$ 。排第二的是 蹄盖偋属, 有 82 种，占该科特有种的 $48.52 \%$, 占该 属种数的 $59.85 \%$ 。第三是鳞毛硕属, 有 61 个, 连同 耳蒝属共有 201 个，占鳞毛葓科特有种的 $78.21 \%$ (附录4)。

\section{3 讨论}

\section{1 中国石松类和蕨类植物在全世界的地位}

中国拥有丰富的蕨类植物, 尤其在喜马拉雅地 区, 海拔和气候变化差异大, 在垂直地带上, 植被 从低海拔的热带雨林向高海拔的高山草甸甚至冰 川过渡, 该区域是中国植物最丰富的地区，也是世 界植物多样性的热点地区之一。另外两个石松类和 茛类植物聚集地是马来群岛和美洲中部(包括墨西 哥及巴西和秘鲁之间的广大地带)。就国家而言, 中 国可能具有全世界最丰富的石松类和偋类植物(印 度尼西亚缺乏可靠数据), 远高于其他国家和地区 (附录5)。

\section{2 中国石松类和築类植物的地理分布特点}

中国拥有如此丰富的石松类和蒝类植物与中 国独特的地理环境密切相关, 尤其是喜马拉雅的隆 起对中国石松类和䓲类植物区系组成具有重要的 影响, 许多类群在该地区形成较多的特有种, 成为 该类群在喜马拉雅地区的分布中心。如中国石松类 和硕类植物的两个优势科鳞毛葓科和蹄盖硕科, 二 者共有 828 种, 占中国石松类和䓲类植物种类总种 数的 $36.48 \%$, 且尤以鳞毛蒝属、耳蒝属和蹄盖硕属 居多, 这三属均以喜马拉雅为分布中心(秦仁昌和 武素功, 1980), 向华东递减, 因此有学者形象地将 喜马拉雅经我国西南至华东到日本这一区域称为 耳硕-鳞毛硕植物区系(孔宪需, 1984)。

中国华南地区属于热带及亚热带气候, 䓲类种 类丰富, 除了广泛分布的一些大属, 如双盖䓲属 (Diplazium) 和鳞盖烣属(Microlepia) 外, 还有一些小 
型的代表科属, 如荷包硕属(Calymmodon)、莎草硕 科(Schizaeaceae)、卤鳚属(Acrostichum)、车前蒝属 (Antrophyum) 和光叶藤偋属(Stenochlaena) 等。需要 指出的是, 台湾、海南等热带岛屿虽然远离喜马拉 雅山脉的莿类分布中心, 但由于其地理位置的特殊 性, 其区系成分具有明显的热带亲缘, 种类组成远 高于中国东部其他省份, 尤其在科属等级上。有些 属在中国仅分布在台湾、海南等热带岛屿, 如合囊 蕨属(Ptisana)、竹叶蕨属(Taenitis)、达边蕨属 (Tapeinidium) 和扫把蕨属(Diploblechnum), 这些属 属于典型的热带亚洲分布, 表明台湾和海南的硕类 区系组成受到明显的热带亚洲植物区系影响。

中国西北、华北及青藏高原地区种类贫乏，主 要分布一些矮小的耐旱、耐寒的种类, 如冷萍属、 珠蕨属(Cryptogramma)、粉背蒴属(Aleuritopteris)、 药葓(Asplenium ceterach)和岩偋科(Woodsiaceae)的 一些种类。中国东北地区种类也很少，但该地区分 布着一些特殊的石松类和蕨类属种，如亮叶石杉 (Huperzia lucida)、对开烣(Asplenium komarovii)、假 鳞毛蒝属 $($ Oreopteris $)$ 和球子蕨属 $($ Onoclea $)$ 等, 这些 属种属于东亚-北美间断分布类群; 中国东北地区 是东亚-北美间断分布成分分布最为集中的地区。

\section{参考文献}

Chapman AD (2009) Numbers of Living Species in Australia and the World, 2nd edn. A Report for the Australian Biological Resources Study. Australian Biodiversity Information Services, Toowoomba, Australia.

Ching RC (1978a) The Chinese fern families and genera: systematic arrangement and historical origin. Acta Phytotaxonomica Sinica, 16(3), 1-19. (in Chinese) [秦仁昌 (1978) 中国偋类植物科属的系统排列和历史来源. 植物分类学 报, 16(3), 1-19.]

Ching RC (1978b) The Chinese fern families and genera: systematic arrangement and historical origin (cont.). Acta Phytotaxonomica Sinica, 16(4), 16-37. (in Chinese) [秦仁昌 (1978) 中国莿类植物科属的系统排列和历史来源(续). 植物分类学报, 16(4), 16-37.]

Ching RC, Wu SK (1980) The floristic characteristics of the Xizang (Tibet) pteridophyte flora in relation to the upheaval of the Himalayas. Acta Botanica Yunnanica, 2, 382-389. (in Chinese) [秦仁昌, 武素功 (1980) 西藏蕨类植物区系的 特点及其与喜马拉雅隆升的关系. 云南植物研究, 2 , 382-389.]

Christenhusz M, Zhang XC, Schneider H (2011) A linear sequence of extant families and genera of lycophytes and ferns. Phytotaxa, 19, 7-54.
Christenhusz M, Schneider H (2011) Corrections to phytotaxa 19: linear sequence of lycophytes and ferns. Phytotaxa, 28, $50-52$.

Delecti Florae Reipublicae Popularis Sinicae Agendae Academiae Sinicae (1959-2000) Flora Reipublicae Popularis Sinicae, Tomus 2-6. Science Press, Beijing. (in Chinese) [《中国植物志》编辑委员会 (1959-2000) 中国植物志, 2-6卷. 科学出版社, 北京.]

Kong XX (1984) The phytogeographical features of pteridophytes of Sichuan, China with some remarks on the "polysticho-dryopteris flora". Acta Botanica Yunnanica, 6, 27-38. (in Chinese with English abstract) [孔宪需 (1984) 四川硕 类植物地理特点兼论 “耳蒴一鳞毛蕨类植物区系”, 云南 植物研究, 6, 27-38.]

Liu HM, Jiang RH, Guo J, Hovenkamp P, Perrie LR, Shepherd L, Hennequin S, Schneider H (2013) Towards a phylogenetic classification of the climbing fern genus Arthropteris. Taxon, 62, 688-700.

Pryer KM, Schneider H, Smith AR, Cranfill R, Wolf PG, Hunt JS, Sipes SD (2001) Horsetails and ferns are a monophyletic group and the closest living relatives to seed plants. Nature, 409, 618-622.

Shrestha N, Xing FW, Qi XP, Yan YH, Zhang XC (2014) Huperziana nlingensis (Lycopodiaceae), a new terrestrial firmoss from southern China. Phytotaxa, 173, 73-79.

Shrestha N, Zhang XC (2015a) On the presence of north American clubmoss Huperzia lucidula (Lycopodiaceae) in China: an intercontinental disjunction or misidentification. Phytotaxa, 219, 243-252.

Shrestha N, Zhang XC (2015b) Recircumscription of Huperzia serrata complex in China using morphological and climatic data. Journal of Systematics and Evolution, 53, 88-103.

Smith AR, Pryer KM, Schuettpelz E, Korall P, Schneider H, Wolf PG (2006) A classification for extant ferns. Taxon, 55, 705-731.

Tan YH, Wei R, Li JW, Zhang XC (2015) Didymochlaena Desv. (Hypodematiaceae): a newly recorded fern genus to China. Plant Diversity and Resources, 37, 135-138. (in Chinese with English abstract) [谭运洪, 卫然, 李剑武, 张 宪春 (2015) 中国肿足蕨科一新记录属——翼囊蕨属. 植物分类与资源学报, 37, 135-138.]

Wang W, Yang WL, Mao XX, Zhao RR, Dou P, Zhang GM (2015) The phylogenetic affinities of Pellaea connectens, a rare endemic Chinese fern. Phytotaxa, 220, 30-42.

Wei R, Zhang XC (2014) Rediscovery of Cystoathyrium chinense Ching (Cystopteridaceae): phylogenetic placement of the critically endangered fern species endemic to China. Journal of Systematics and Evolution, 52, 450-457.

Wu SH, Ching RC (1991) Fern Families and Genera of China. Science Press, Beijing. (in Chinese) [吴兆洪, 秦仁昌 (1991) 中国蕨类植物科属志. 科学出版社, 北京.]

Wu ZY, Raven P, Hong DY (2013) Flora of China. Vol. 2-3 (Pteridophytes). Science Press, Beijing \& Missouri Botanical Garden Press, St. Louis. 
Yan YH, Zhang XC, Ma KP (2013) Pteridophytes in China: Diversity and Distribution. Science Press, Beijing. (in Chinese) [严岳鸿, 张宪春, 马克平 (2013) 中国蕨类植物多 样性与地理分布. 科学出版社, 北京.]

Zhang LB, Zhang L (2015) Didymochlaenaceae: a new fern family of Eupolypods I (Polypodiales). Taxon, 64, 27-38.

Zhang XC (2012) Lycophytes and Ferns of China. Peking University Press, Beijing. (in Chinese) [张宪春 (2012) 中 国石松类和蕨类植物. 北京大学出版社, 北京.]
Zhang XC, Wei R, Liu HM, He LJ, Wang L, Zhang GM (2013) Phylogeny and classification of the extant lycophytes and ferns from China. Chinese Bulletin of Botany, 48, 119-137. (in Chinese with English abstract) [张宪春, 卫然, 刘红梅, 何丽娟, 王丽, 张钢民 (2013) 中国现代石松类和蕨类的 系统发育与分类系统. 植物学报, 48, 119-137.]

(责任编委: 李振宇 责任编辑: 间文杰)

\section{附录 Supplementary Material}

附录1 中国石松类和蕨类植物的科属种组成

Appendix 1 No. of genera and species in families of lycophytes and ferns in China http://www.biodiversity-science.net/fileup/PDF/2015256-1.pdf

附录2 中国石松类和茨类植物属中种数

Appendix 2 No. of species in genera of lycophytes and ferns in China http://www.biodiversity-science.net/fileup/PDF/2015256-2.pdf

附录3 中国石松类和蕨类植物科中特有种数统计

Appendix 3 No. of endemic species in families of lycophytes and ferns in China http://www.biodiversity-science.net/fileup/PDF/2015256-3.pdf

附录4 中国石松类和䓲类植物属中特有种数统计

Appendix 4 No. of endemic species in genera of lycophytes and ferns in China http://www.biodiversity-science.net/fileup/PDF/2015256-4.pdf

附录5 中国和世界植物热点地区的石松类和斴类植物比较

Appendix 5 Comparison of lycophytes and ferns in China with plant hot regions in the world http://www.biodiversity-science.net/fileup/PDF/2015256-5.pdf 
周喜乐, 张宪春, 孙久琼, 严岳鸿. 中国石松类和蓱类植物的多样性与地理分布. 生物多样性, 2016, 24 (1), 102-107. http://www.biodiversity-science.net/CN/10.17520/biods.2015256

附录1 中国石松类和烣类植物的科属种组成

Appendix 1 No. of genera and species in families of lycophytes and ferns in China

\begin{tabular}{|c|c|c|c|c|c|}
\hline $\begin{array}{l}\text { 科名 } \\
\text { Family }\end{array}$ & $\begin{array}{c}\text { 属数 } \\
\text { No. of genus }\end{array}$ & $\begin{array}{c}\text { 种数 } \\
\text { No. of species }\end{array}$ & $\begin{array}{c}\text { 变种 } \\
\text { No. of variety }\end{array}$ & $\begin{array}{c}\text { 亚种 } \\
\text { No. of subspecies }\end{array}$ & $\begin{array}{c}\text { 种亚种变种总和 } \\
\text { Total }\end{array}$ \\
\hline 鳞毛硕科 Dryopteridaceae & 10 & 496 & 8 & 1 & 505 \\
\hline 蹄盖蕨科 Athyriaceae & 5 & 282 & 41 & & 323 \\
\hline 水龙骨科 Polypodiaceae & 39 & 267 & 13 & & 280 \\
\hline 凤尾䯾科 Pteridaceae & 21 & 235 & 31 & & 266 \\
\hline 金星濒科 Thelypteridaceae & 18 & 199 & 10 & & 209 \\
\hline 铁角蕨科 Aspleniaceae & 2 & 108 & 2 & & 110 \\
\hline 卷柏科 Selaginellaceae & 1 & 73 & & & 73 \\
\hline 石松科 Lycopodiaceae & 5 & 69 & 1 & & 70 \\
\hline 碗蕨科 Dennstaedtiaceae & 7 & 53 & 6 & & 59 \\
\hline 膜蕨科 Hymenophyllaceae & 7 & 51 & 2 & & 53 \\
\hline 叉蕨科 Tectariaceae & 3 & 40 & & & 40 \\
\hline 合囊蕨科 Marattiaceae & 3 & 30 & & & 30 \\
\hline 岩蕨科 Woodsiaceae & 3 & 24 & & & 24 \\
\hline 瓶尔小草科 Ophioglossaceae & 3 & 22 & & & 22 \\
\hline 冷蕨科 Cystopteridaceae & 3 & 20 & & & 20 \\
\hline 鳞始硕科 Lindsaeaceae & 4 & 17 & 1 & 1 & 19 \\
\hline 骨碎补科 Davalliaceae & 4 & 17 & & & 17 \\
\hline 里白科 Gleicheniaceae & 3 & 16 & & & 16 \\
\hline 乌毛蕨科 Blechnaceae & 8 & 14 & 1 & & 15 \\
\hline 杪椤科 Cyatheaceae & 2 & 14 & & & 14 \\
\hline 肿足溦科 Hypodematiaceae & 2 & 13 & & & 13 \\
\hline 木贼科 Equisetaceae & 1 & 10 & & 3 & 13 \\
\hline 海金沙科 Lygodiaceae & 1 & 9 & & & 9 \\
\hline 紫萁科 Osmundaceae & 2 & 8 & & & 8 \\
\hline 瘤足鄀科 Plagiogyriaceae & 1 & 8 & & & 8 \\
\hline 肾烣科 Nephrolepidaceae & 1 & 5 & 1 & & 6 \\
\hline 水非科 Isoëtaceae & 1 & 5 & & & 5 \\
\hline 双扇蕨科 Dipteridaceae & 2 & 5 & & & 5 \\
\hline 轴果硕科 Rhachidosoraceae & 1 & 5 & & & 5 \\
\hline 藤蕨科 Oleandraceae & 1 & 5 & & & 5 \\
\hline 球子蕼科 Onocleaceae & 3 & 4 & 1 & & 5 \\
\hline 槐叶蘋科 Salviniaceae & 2 & 5 & & & 5 \\
\hline 藤蕨科 Lomariopsidaceae & 2 & 4 & & & 4 \\
\hline 蘋科 Marsileaceae & 1 & 3 & & & 3 \\
\hline 肠蕨科 Diplaziopsidaceae & 1 & 3 & & & 3 \\
\hline 莎草蕨科 Schizaeaceae & 1 & 2 & & & 2 \\
\hline 金毛狗蕨科 Cibotiaceae & 1 & 2 & & & 2 \\
\hline 爬树硕科 Arthropteridaceae & 1 & 2 & & & 2 \\
\hline 松叶蕨科 Psilotaceae & 1 & 1 & & & 1 \\
\hline 翼盖蕨科 Didymochlaenaceae & 1 & 1 & & & 1 \\
\hline 总计 Total & 178 & 2,147 & 118 & 5 & 2,270 \\
\hline
\end{tabular}


周喜乐, 张宪春, 孙久琼, 严岳鸿. 中国石松类和蕨类植物的多样性与地理分布. 生物多样性, 2016, 24 (1), $102-107$. http://www.biodiversity-science.net/CN/10.17520/biods.2015256

附录2 中国石松类和蕨类植物属中种数

Appendix 2 No. of species in genera of lycophytes and ferns in China

\begin{tabular}{|c|c|c|c|c|c|}
\hline $\begin{array}{c}\text { 属名 } \\
\text { Genus }\end{array}$ & $\begin{array}{l}\text { 所属科 } \\
\text { Family }\end{array}$ & $\begin{array}{c}\text { 种 } \\
\text { Species }\end{array}$ & $\begin{array}{l}\text { 变种 } \\
\text { Variety }\end{array}$ & $\begin{array}{c}\text { 亚种 } \\
\text { Subspecies }\end{array}$ & $\begin{array}{c}\text { 种亚种变种总和总数 } \\
\text { Total }\end{array}$ \\
\hline 耳硕属 Polystichum & 鳞毛萍科 & 209 & & & 209 \\
\hline 鳞毛䯾属 Dryopteris & 鳞毛蕨科 & 169 & 6 & 1 & 176 \\
\hline 蹄盖凮属 Athyrium & 蹄盖烣科 & 124 & 13 & & 137 \\
\hline 双盖烣属 Diplazium & 蹄盖蕨科 & 87 & 11 & & 98 \\
\hline 凤尾葓属 Pteris & 凤尾蕨科 & 79 & 18 & & 97 \\
\hline 铁角蕨属 Asplenium & 铁角蕨科 & 90 & 2 & & 92 \\
\hline 卷柏属 Selaginella & 卷柏科 & 73 & & & 73 \\
\hline 对囊硕属 Deparia & 蹄盖偋科 & 55 & 17 & & 72 \\
\hline 瓦韦属 Lepisorus & 水龙骨科 & 49 & 2 & & 51 \\
\hline 修蕨属 Selliguea & 水龙骨科 & 48 & 1 & & 49 \\
\hline 毛蕨属 Cyclosorus & 金星蕨科 & 40 & 2 & & 42 \\
\hline 复叶耳蕨属 Arachniodes & 鳞毛蕨科 & 40 & & & 40 \\
\hline 铁线蕨属 Adiantum & 凤尾烣科 & 35 & 3 & & 38 \\
\hline 假毛蕨属 Pseudocyclosorus & 金星硕科 & 38 & & & 38 \\
\hline 叉蕨属 Tectaria & 叉蕨科 & 35 & & & 35 \\
\hline 粉背瞢属 Aleuritopteris & 凤尾蕨科 & 29 & 4 & & 33 \\
\hline 石韦属 Pyrrosia & 水龙骨科 & 32 & & & 32 \\
\hline 贯众属 Cyrtomium & 鳞毛蕨科 & 31 & & & 31 \\
\hline 石杉属 Huperzia & 石松科 & 29 & 1 & & 30 \\
\hline 鳞盖蕨属 Microlepia & 碗䋏科 & 25 & 4 & & 29 \\
\hline 莲座蕨属 Angiopteris & 合囊蕨科 & 28 & & & 28 \\
\hline 金星藃属 Parathelypteris & 金星蕨科 & 24 & 4 & & 28 \\
\hline 凤了蕨属 Coniogramme & 凤尾硕科 & 22 & 3 & & 25 \\
\hline 实蕨属 Bolbitis & 鳞毛蕨科 & 25 & & & 25 \\
\hline 马尾杉属 Phlegmariurus & 石松科 & 23 & & & 23 \\
\hline 膜蕨属 Hymenophyllum & 膜蕨科 & 23 & & & 23 \\
\hline 岩蕨属 Woodsia & 岩蕨科 & 20 & & & 20 \\
\hline 节肢蕨属 Arthromeris & 水龙骨科 & 17 & 1 & & 18 \\
\hline 膜叶铁角蕨属 Hymenasplenium & 铁角蕨科 & 18 & & & 18 \\
\hline 新月蒴属 Pronephrium & 金星硕科 & 18 & & & 18 \\
\hline 碎米蕨属 Cheilanthes & 凤尾蕨科 & 17 & & & 17 \\
\hline 薄唇蕨属 Leptochilus & 凤尾蕨科 & 13 & 4 & & 17 \\
\hline 石松属 Lycopodium & 石松科 & 14 & & & 14 \\
\hline 书带蓱属 Haplopteris & 凤尾葓科 & 14 & & & 14 \\
\hline 木贼属 Equisetum & 木贼科 & 10 & & 3 & 13 \\
\hline 鳞始蕨属 Lindsaea & 鳞始鄀科 & 12 & & 1 & 13 \\
\hline 紫柄蕨属 Pseudophegopteris & 金星硕科 & 12 & 1 & & 13 \\
\hline 水龙骨属 Polypodiodes & 水龙骨科 & 11 & 2 & & 13 \\
\hline 角蕨属 Cornopteris & 蹄盖蕨科 & 12 & & & 12 \\
\hline 阴地蕨属 Botrychium & 瓶尔小草科 & 12 & & & 12 \\
\hline 假脉蕨属 Crepidomanes & 膜蕨科 & 11 & 1 & & 12 \\
\hline 杪椤属 Alsophila & 杪椤科 & 12 & & & 12 \\
\hline 凸轴蕨属 Metathelypteris & 金星硕科 & 11 & 1 & & 12 \\
\hline 肿足烣属 Hypodematium & 肿足蕨科 & 12 & & & 12 \\
\hline 剑蕨属 Loxogramme & 水龙骨科 & 12 & & & 12 \\
\hline
\end{tabular}


周喜乐, 张宪春, 孙久琼, 严岳鸿. 中国石松类和蓱类植物的多样性与地理分布. 生物多样性, 2016, 24 (1), 102-107. http://www.biodiversity-science.net/CN/10.17520/biods.2015256

\begin{tabular}{|c|c|c|c|c|c|}
\hline $\begin{array}{r}\text { 属名 } \\
\text { Genus }\end{array}$ & $\begin{array}{l}\text { 所属科 } \\
\text { Family }\end{array}$ & $\begin{array}{c}\text { 种 } \\
\text { Species }\end{array}$ & $\begin{array}{l}\text { 变种 } \\
\text { Variety }\end{array}$ & $\begin{array}{c}\text { 亚种 } \\
\text { Subspecies }\end{array}$ & $\begin{array}{c}\text { 种亚种变种总和总数 } \\
\text { Total }\end{array}$ \\
\hline 冷蕨属 Cystopteris & 冷蕨科 & 12 & & & 12 \\
\hline 方杆菜属 Glaphyropteridopsis & 金星硕科 & 11 & & & 11 \\
\hline 金粉偋属 Onychium & 凤尾蕨科 & 8 & 2 & & 10 \\
\hline 肋毛硕属 Ctenitis & 鳞毛蕨科 & 10 & & & 10 \\
\hline 车前濒属 Antrophyum & 凤尾硕科 & 9 & & & 9 \\
\hline 瓶尔小草属 Ophioglossum & 瓶尔小草科 & 9 & & & 9 \\
\hline 里白属 Diplopterygium & 里白科 & 9 & & & 9 \\
\hline 海金沙属 Lygodium & 海金沙科 & 9 & & & 9 \\
\hline 碗睰属 Dennstaedtia & 碗瞢科 & 8 & 1 & & 9 \\
\hline 钩毛蕨属 Cyclogramma & 金星蕨科 & 9 & & & 9 \\
\hline 茯蕨属 Leptogramma & 金星硕科 & 9 & & & 9 \\
\hline 檞蕨属 Drynaria & 水龙骨科 & 9 & & & 9 \\
\hline 瘤足颐属 Plagiogyria & 瘤足硕科 & 8 & & & 8 \\
\hline 姬鄀属 Hypolepis & 碗嵚科 & 8 & & & 8 \\
\hline 针毛蕨属 Macrothelypteris & 金星蕨科 & 7 & 1 & & 8 \\
\hline 舌蕨属 Elaphoglossum & 鳞毛蕨科 & 6 & 2 & & 8 \\
\hline 紫萁属 Osmunda & 紫萁科 & 7 & & & 7 \\
\hline 瓶蕨属 Vandenboschia & 膜蕨科 & 7 & & & 7 \\
\hline 濒属 Pteridium & 碗偋科 & 6 & 1 & & 7 \\
\hline 滨禾硕属 Oreogrammitis & 水龙骨科 & 7 & & & 7 \\
\hline 穴子鄀属 Prosaptia & 水龙骨科 & 7 & & & 7 \\
\hline 金毛裸蕨属 Paragymnopteris & 凤尾蕨科 & 5 & 1 & & 6 \\
\hline 溪边鄀属 Stegnogramma & 金星蕨科 & 6 & & & 6 \\
\hline 肾蕨属 Nephrolepis & 肾蕨科 & 5 & 1 & & 6 \\
\hline 骨碎补属 Davallia & 骨碎补科 & 6 & & & 6 \\
\hline 伏石蕨属 Lemmaphyllum & 水龙骨科 & 5 & 1 & & 6 \\
\hline 星蕨属 Microsorum & 水龙骨科 & 5 & 1 & & 6 \\
\hline 瘤蕨属 Phymatosorus & 水龙骨科 & 6 & & & 6 \\
\hline 芒其属 Dicranopteris & 里白科 & 6 & & & 6 \\
\hline 盾葓属 Neolepisorus & 水龙骨科 & 5 & & & 5 \\
\hline 水非属 Isoëtes & 水非科 & 5 & & & 5 \\
\hline 毛边蕨属 Didymoglossum & 膜蕨科 & 5 & & & 5 \\
\hline 羽节嵚属 Gymnocarpium & 冷蔂科 & 5 & & & 5 \\
\hline 轴果蕨属 Rhachidosorus & 轴果蕨科 & 5 & & & 5 \\
\hline 狗脊属 Woodwardia & 乌毛鄀科 & 5 & & & 5 \\
\hline 葆蒴属 Oleandra & 葆蒴科 & 5 & & & 5 \\
\hline 长片䕬属 Abrodictyum & 膜瞢科 & 3 & 1 & & 4 \\
\hline 圣蕨属 Dictyocline & 金星蕨科 & 4 & & & 4 \\
\hline 安硕属 Anisocampium & 蹄盖珮科 & 4 & & & 4 \\
\hline 小膜盖嵚属 Araiostegia & 骨碎补科 & 4 & & & 4 \\
\hline 阴石葻属 Humata & 骨碎补科 & 4 & & & 4 \\
\hline 拟水龙骨属 Polypodiastrum & 水龙骨科 & 3 & 1 & & 4 \\
\hline 辐禾嵚属 Radiogrammitis & 水龙骨科 & 4 & & & 4 \\
\hline 双扇瞢属 Dipteris & 双扇瞢科 & 3 & & & 3 \\
\hline 蘋属 Marsilea & 蘋科 & 3 & & & 3 \\
\hline 稀子偋属 Monachosorum & 碗蕨科 & 3 & & & 3 \\
\hline 珠颐属 Cryptogramma & 凤尾硕科 & 3 & & & 3 \\
\hline
\end{tabular}


周喜乐, 张宪春, 孙久琼, 严岳鸿. 中国石松类和蓱类植物的多样性与地理分布. 生物多样性, 2016, 24 (1), 102-107. http://www.biodiversity-science.net/CN/10.17520/biods.2015256

\begin{tabular}{|c|c|c|c|c|c|}
\hline $\begin{array}{l}\text { 属名 } \\
\text { Genus }\end{array}$ & $\begin{array}{l}\text { 所属科 } \\
\text { Family }\end{array}$ & $\begin{array}{c}\text { 种 } \\
\text { Species }\end{array}$ & $\begin{array}{l}\text { 变种 } \\
\text { Variety }\end{array}$ & $\begin{array}{c}\text { 亚种 } \\
\text { Subspecies }\end{array}$ & $\begin{array}{c}\text { 种亚种变种总和总数 } \\
\text { Total }\end{array}$ \\
\hline 亮毛蕨属 Acystopteris & 冷蕨科 & 3 & & & 3 \\
\hline 肠蕨属 Diplaziopsis & 肠蕨科 & 3 & & & 3 \\
\hline 卵果蓱属 Phegopteris & 金星蕨科 & 3 & & & 3 \\
\hline 沼泽硕属 Thelypteris & 金星蕨科 & 2 & 1 & & 3 \\
\hline 滇蕨属 Cheilanthopsis & 岩蕨科 & 3 & & & 3 \\
\hline 荚囊蕨属 Struthiopteris & 乌毛硕科 & 2 & 1 & & 3 \\
\hline 节毛髶属 Lastreopsis & 鳞毛蕨科 & 3 & & & 3 \\
\hline 藤蕪属 Lomariopsis & 藤嵚科 & 3 & & & 3 \\
\hline 牙蕨属 Pteridrys & 叉蕨科 & 3 & & & 3 \\
\hline 假钻毛媭属 Paradavallodes & 骨碎补科 & 3 & & & 3 \\
\hline 荷包蕨属 Calymmodon & 水龙骨科 & 3 & & & 3 \\
\hline 鳞果星嵚属 Lepidomicrosorium & 水龙骨科 & 3 & & & 3 \\
\hline 槐叶蘋属 Salvinia & 槐叶蘋科 & 3 & & & 3 \\
\hline 卤蕨属 Acrostichum & 凤尾蕨科 & 2 & & & 2 \\
\hline 小石松属 Lycopodiella & 石松科 & 2 & & & 2 \\
\hline 燕尾蕨属 Cheiropleuria & 双扇蒝科 & 2 & & & 2 \\
\hline 莎草蕨属 Schizaea & 莎草蕨科 & 2 & & & 2 \\
\hline 满江红属 Azolla & 槐叶蘋科 & 2 & & & 2 \\
\hline 金毛狗蕨属 Cibotium & 金毛狗科 & 2 & & & 2 \\
\hline 白桫椤属 Sphaeropteris & 杪椤科 & 2 & & & 2 \\
\hline 乌鄀属 Odontosoria & 鳞始蓱科 & 2 & & & 2 \\
\hline 香鳞始蕨属 Osmolindsaea & 鳞始蕨科 & 2 & & & 2 \\
\hline 达边葓属 Tapeinidium & 鳞始蕨科 & 1 & 1 & & 2 \\
\hline 翠菜属 Anogramma & 凤尾硕科 & 2 & & & 2 \\
\hline 水蕨属 Ceratopteris & 凤尾蕨科 & 2 & & & 2 \\
\hline 一条线䝫属 Monogramma & 凤尾硕科 & 2 & & & 2 \\
\hline 假鳞毛颐属 Oreopteris & 金星蕨科 & 2 & & & 2 \\
\hline 荚果蕨属 Matteuccia & 球子䯾科 & 1 & 1 & & 2 \\
\hline 东方荚果蕨属 Pentarhizidium & 球子蕨科 & 2 & & & 2 \\
\hline 崇澍蕨属 Chieniopteris & 乌毛蕨科 & 2 & & & 2 \\
\hline 网藤菜属 Lomagramma & 鳞毛蕨科 & 2 & & & 2 \\
\hline 黄腺羽蕨属 Pleocnemia & 叉蕨科 & 2 & & & 2 \\
\hline 爬树䕬属 Arthropteris & 爬树硕科 & 2 & & & 2 \\
\hline 连珠藃属 Aglaomorpha & 水龙骨科 & 2 & & & 2 \\
\hline 棱脉烣属 Goniophlebium & 水龙骨科 & 2 & & & 2 \\
\hline 篦齿鄀属 Metapolypodium & 水龙骨科 & 2 & & & 2 \\
\hline 锯䯾属 Micropolypodium & 水龙骨科 & 2 & & & 2 \\
\hline 扇蕨属 Neocheiropteris & 水龙骨科 & 2 & & & 2 \\
\hline 多足蕨属 Polypodium & 水龙骨科 & 2 & & & 2 \\
\hline 蒿蕨属 Themelium & 水龙骨科 & 2 & & & 2 \\
\hline 旱蕨属 Pellaea & 凤尾蕨科 & 1 & & & 1 \\
\hline 钝旱蕨属 Argyrochosma & 凤尾蒝科 & 1 & & & 1 \\
\hline 藤石松属 Lycopodiastrum & 石松科 & 1 & & & 1 \\
\hline 七指蕨属 Helminthostachys & 瓶尔小草科 & 1 & & & 1 \\
\hline 松叶蕨属 Psilotum & 松叶蕨科 & 1 & & & 1 \\
\hline 合囊瞢属 Ptisana & 合囊蕨科 & 1 & & & 1 \\
\hline 天星濒属 Christensenia & 合囊蕨科 & 1 & & & 1 \\
\hline
\end{tabular}


周喜乐, 张宪春, 孙久琼, 严岳鸿. 中国石松类和蓱类植物的多样性与地理分布. 生物多样性, 2016, 24 (1), 102-107. http://www.biodiversity-science.net/CN/10.17520/biods.2015256

\begin{tabular}{|c|c|c|c|c|c|}
\hline $\begin{array}{c}\text { 属名 } \\
\text { Genus }\end{array}$ & $\begin{array}{l}\text { 所属科 } \\
\text { Family }\end{array}$ & $\begin{array}{c}\text { 种 } \\
\text { Species }\end{array}$ & $\begin{array}{c}\text { 变种 } \\
\text { Variety }\end{array}$ & $\begin{array}{c}\text { 亚种 } \\
\text { Subspecies }\end{array}$ & $\begin{array}{c}\text { 种亚种变种总和总数 } \\
\text { Total } \\
\end{array}$ \\
\hline 桂皮紫其属 Osmundastrum & 紫其科 & 1 & & & 1 \\
\hline 毛杆藃属 Callistopteris & 膜硕科 & 1 & & & 1 \\
\hline 厚叶烣属 Cephalomanes & 膜偋科 & 1 & & & 1 \\
\hline 假芒萁属 Sticherus & 里白科 & 1 & & & 1 \\
\hline 栗硕属 Histiopteris & 碗硕科 & 1 & & & 1 \\
\hline 曲轴蒝属 Paesia & 碗硕科 & 1 & & & 1 \\
\hline 戟叶黑心葓属 Calciphilopteris & 凤尾䰻科 & 1 & & & 1 \\
\hline 黑心硕属 Doryopteris & 凤尾硕科 & 1 & & & 1 \\
\hline 泽泻蕨属 Parahemionitis & 凤尾藓科 & 1 & & & 1 \\
\hline 粉叶蕨属 Pityrogramma & 凤尾眇科 & 1 & & & 1 \\
\hline 竹叶硕属 Taenitis & 凤尾蒝科 & 1 & & & 1 \\
\hline 星毛鄀属 Ampelopteris & 金星菜科 & 1 & & & 1 \\
\hline 边果偋属 Craspedosorus & 金星蒴科 & 1 & & & 1 \\
\hline 龙津蕨属 Mesopteris & 金星蕨科 & 1 & & & 1 \\
\hline 膀胱硕属 Protowoodsia & 岩偋科 & 1 & & & 1 \\
\hline 球子蕨属 Onoclea & 球子蒴科 & 1 & & & 1 \\
\hline 乌木蕨属 Blechnidium & 乌毛鄀科 & 1 & & & 1 \\
\hline 乌毛䕬属 Blechnum & 乌毛蒴科 & 1 & & & 1 \\
\hline 苏铁蕨属 Brainea & 乌毛蕨科 & 1 & & & 1 \\
\hline 扫把硕属 Diploblechnum & 乌毛偋科 & 1 & & & 1 \\
\hline 光叶藤蕨属 Stenochlaena & 乌毛䕬科 & 1 & & & 1 \\
\hline 翼盖萨属 Didymochlaena & 翼盖萍科 & 1 & & & 1 \\
\hline 大膜盖蕨属 Leucostegia & 肿足蕨科 & 1 & & & 1 \\
\hline 符藤蕨属 Teratophyllum & 鳞毛蕨科 & 1 & & & 1 \\
\hline 拟贯众属 Cyclopeltis & 藤蕨科 & 1 & & & 1 \\
\hline 高平葓属 Caobangia & 水龙骨科 & 1 & & & 1 \\
\hline 戟蒴属 Christopteris & 水龙骨科 & 1 & & & 1 \\
\hline 金禾菜属 Chrysogrammitis & 水龙骨科 & 1 & & & 1 \\
\hline 小蒿蕨属 Ctenopterella & 水龙骨科 & 1 & & & 1 \\
\hline 毛禾蕨属 Dasygrammitis & 水龙骨科 & 1 & & & 1 \\
\hline 雨蕨属 Gymnogrammitis & 水龙骨科 & 1 & & & 1 \\
\hline 锡金假瘤蕨属 Himalayopteris & 水龙骨科 & 1 & & & 1 \\
\hline 顶育偋属 Photinopteris & 水龙骨科 & 1 & & & 1 \\
\hline 鹿角蕨属 Platycerium & 水龙骨科 & 1 & & & 1 \\
\hline 睫毛硕属 Pleurosoriopsis & 水龙骨科 & 1 & & & 1 \\
\hline 革舌鄀属 Scleroglossum & 水龙骨科 & 1 & & & 1 \\
\hline 裂禾蒴属 Tomophyllum & 水龙骨科 & 1 & & & 1 \\
\hline 毛鳞鄀属 Tricholepidium & 水龙骨科 & 1 & & & 1 \\
\hline 剑羽蕨属 Xiphopterella & 水龙骨科 & 1 & & & 1 \\
\hline 总计 Total & & 2,147 & 118 & 5 & 2,270 \\
\hline
\end{tabular}


周喜乐, 张宪春, 孙久琼, 严岳鸿. 中国石松类和蓱类植物的多样性与地理分布. 生物多样性, 2016, 24 (1), 102-107.

http://www.biodiversity-science.net/CN/10.17520/biods.2015256

附录3 中国石松类和茨类植物科中特有种数统计

Appendix 3 No. of endemic species in families of lycophytes and ferns in China

\begin{tabular}{|c|c|c|c|c|}
\hline 科名 Family & $\begin{array}{c}\text { 特有种 } \\
\text { Species endemic to China (SEC) }\end{array}$ & $\begin{array}{c}\text { 含特有种的属 } \\
\text { Genera with SEC }\end{array}$ & $\begin{array}{c}\text { 占科中种数比例 } \\
\text { Accounting for species in } \\
\text { family (\%) }\end{array}$ & $\begin{array}{c}\text { 占总特有种比例 } \\
\text { SEC in family account- } \\
\text { ing for total SEC (\%) }\end{array}$ \\
\hline 鳞毛䕬科 Dryopteridaceae & 257 & 10 & 50.89 & 28.09 \\
\hline 蹄盖蕨科 Athyriaceae & 169 & 4 & 52.32 & 18.47 \\
\hline 凤尾蔓科 Pteridaceae & 113 & 12 & 42.48 & 12.35 \\
\hline 金星颐科 Thelypteridaceae & 107 & 14 & 51.20 & 11.69 \\
\hline 水龙骨科 Polypodiaceae & 88 & 15 & 31.43 & 9.62 \\
\hline 石松科 Lycopodiaceae & 31 & 3 & 44.29 & 3.39 \\
\hline 铁角葓科 Aspleniaceae & 25 & 2 & 22.73 & 2.73 \\
\hline 卷柏科 Selaginellaceae & 23 & 1 & 31.51 & 2.51 \\
\hline 碗蕨科 Dennstaedtiaceae & 18 & 4 & 30.51 & 1.97 \\
\hline 合囊蕨科 Marattiaceae & 16 & 1 & 53.33 & 1.75 \\
\hline 冷硕科 Cystopteridaceae & 9 & 4 & 45.00 & 0.98 \\
\hline 岩硕科 Woodsiaceae & 9 & 2 & 37.50 & 0.98 \\
\hline 肿足烣科 Hypodematiaceae & 8 & 1 & 61.54 & 0.87 \\
\hline 膜濒科 Hymenophyllaceae & 7 & 2 & 13.21 & 0.77 \\
\hline 叉蕨科 Tectariaceae & 7 & 2 & 17.50 & 0.77 \\
\hline 里白科 Gleicheniaceae & 5 & 2 & 31.25 & 0.55 \\
\hline 水韭科 Isoëtaceae & 5 & 1 & 100.00 & 0.55 \\
\hline 轴果媭科 Rhachidosoraceae & 3 & 1 & 60.00 & 0.33 \\
\hline 骨碎补科 Davalliaceae & 3 & 3 & 17.65 & 0.33 \\
\hline 瓶尔小草科 Ophioglossaceae & 2 & 1 & 9.09 & 0.22 \\
\hline 乌毛硕科 Blechnaceae & 2 & 1 & 13.33 & 0.22 \\
\hline 紫其科 Osmundaceae & 1 & 1 & 12.50 & 0.11 \\
\hline 瘤足硕科 Plagiogyriaceae & 1 & 1 & 12.50 & 0.11 \\
\hline 杪椤科 Cyatheaceae & 1 & 1 & 7.14 & 0.11 \\
\hline 鳞始蕨科 Lindsaeaceae & 1 & 1 & 5.26 & 0.11 \\
\hline 球子硕科 Onocleaceae & 1 & 1 & 20.00 & 0.11 \\
\hline 藤蕨科 Lomariopsidaceae & 1 & 1 & 25.00 & 0.11 \\
\hline 肾萩科 Nephrolepidaceae & 1 & 1 & 16.67 & 0.11 \\
\hline 爬树蕨科 Arthropteridaceae & 1 & 1 & 50.00 & 0.11 \\
\hline 总计 Total & 915 & 93 & & 100.00 \\
\hline
\end{tabular}


周喜乐, 张宪春, 孙久琼, 严岳鸿. 中国石松类和蕨类植物的多样性与地理分布. 生物多样性, 2016, 24 (1), $102-107$. http://www.biodiversity-science.net/CN/10.17520/biods.2015256

附录4 中国石松类和莿类植物属中特有种数统计

Appendix 4 No. of endemic species in genera of lycophytes and ferns in China

\begin{tabular}{|c|c|c|c|c|}
\hline 属名 Genus & $\begin{array}{c}\text { 特有种 } \\
\text { Species endemic to } \\
\text { China (SEC) }\end{array}$ & $\begin{array}{c}\text { 占科中特有种数比例 } \\
\text { Accounting for SEC in family } \\
(\%)\end{array}$ & $\begin{array}{c}\text { 占属中种数比例 } \\
\text { Accounting for species in } \\
\text { genus (\%) }\end{array}$ & $\begin{array}{l}\text { 占总特有种比例 } \\
\text { SEC in genus account- } \\
\text { ing for total SEC (\%) }\end{array}$ \\
\hline 耳蕨属 Polystichum & 140 & 54.47 & 66.99 & 15.30 \\
\hline 蹄盖蕨属 Athyrium & 82 & 48.52 & 59.85 & 8.96 \\
\hline 鳞毛蓱属 Dryopteris & 61 & 23.74 & 34.66 & 6.67 \\
\hline 对囊薜属 Deparia & 49 & 28.99 & 68.06 & 5.36 \\
\hline 凤尾薑属 Pteris & 45 & 39.82 & 46.39 & 4.92 \\
\hline 双盖蕨属 Diplazium & 32 & 18.93 & 32.65 & 3.50 \\
\hline 假毛藃属 Pseudocyclosorus & 30 & 28.04 & 78.95 & 3.28 \\
\hline 修蕨属 Selliguea & 29 & 32.95 & 59.18 & 3.17 \\
\hline 瓦韦属 Lepisorus & 23 & 26.14 & 45.10 & 2.51 \\
\hline 卷柏属 Selaginella & 23 & 100.00 & 31.51 & 2.51 \\
\hline 铁线颐属 Adiantum & 21 & 18.58 & 55.26 & 2.30 \\
\hline 石杉属 Huperzia & 21 & 67.74 & 70.00 & 2.30 \\
\hline 贯众属 Cyrtomium & 19 & 7.39 & 61.29 & 2.08 \\
\hline 粉背蕨属 Aleuritopteris & 18 & 15.93 & 54.55 & 1.97 \\
\hline 铁角蕨属 Asplenium & 17 & 68.00 & 18.48 & 1.86 \\
\hline 复叶耳颗属 Arachniodes & 16 & 6.23 & 40.00 & 1.75 \\
\hline 观音座莲属 Angiopteris & 16 & 100.00 & 57.14 & 1.75 \\
\hline 金星硕属 Parathelypteris & 14 & 13.08 & 50.00 & 1.53 \\
\hline 凤Y硕属 Coniogramme & 13 & 11.50 & 52.00 & 1.42 \\
\hline 毛莎属 Cyclosorus & 12 & 11.21 & 28.57 & 1.31 \\
\hline 实蕨属 Bolbitis & 12 & 4.67 & 48.00 & 1.31 \\
\hline 方秆硕属 Glaphyropteridopsis & 10 & 9.35 & 90.91 & 1.09 \\
\hline 鳞盖蕨属 Microlepia & 9 & 50.00 & 31.03 & 0.98 \\
\hline 马尾杉属 Phlegmariurus & 9 & 29.03 & 39.13 & 0.98 \\
\hline 节肢葓属 Arthromeris & 8 & 9.09 & 44.44 & 0.87 \\
\hline 膜叶铁角莜属 Hymenasplenium & 8 & 32.00 & 44.44 & 0.87 \\
\hline 新月蕨属 Pronephrium & 8 & 7.48 & 44.44 & 0.87 \\
\hline 岩蕨属 Woodsia & 8 & 88.89 & 40.00 & 0.87 \\
\hline 肿足蕨属 Hypodematium & 8 & 100.00 & 66.67 & 0.87 \\
\hline 碎米蕨属 Cheilosoria & 7 & 6.19 & 41.18 & 0.77 \\
\hline 钩毛硕属 Cyclogramma & 7 & 6.54 & 77.78 & 0.77 \\
\hline 冷蔽属 Cystopteris & 6 & 66.67 & 50.00 & 0.66 \\
\hline 凸轴硕属 Metathelypteris & 6 & 5.61 & 50.00 & 0.66 \\
\hline 茯鄀属 Leptogramma & 6 & 5.61 & 66.67 & 0.66 \\
\hline 叉烣属 Tectaria & 6 & 85.71 & 17.14 & 0.66 \\
\hline 石韦属 Pyrrosia & 6 & 6.82 & 18.75 & 0.66 \\
\hline 角蕨属 Cornopteris & 5 & 2.96 & 41.67 & 0.55 \\
\hline 溪边鲛属 Stegnogramma & 5 & 4.67 & 83.33 & 0.55 \\
\hline 膜蕨属 Hymenophyllum & 5 & 71.43 & 21.74 & 0.55 \\
\hline 水非属 Isoëtes & 5 & 100.00 & 100.00 & 0.55 \\
\hline 里白属 Hicriopteris & 4 & 80.00 & 44.44 & 0.44 \\
\hline 蕨属 Pteridium & 4 & 22.22 & 57.14 & 0.44 \\
\hline 紫柄蕨属 Pseudophegopteris & 4 & 3.74 & 30.77 & 0.44 \\
\hline 肋毛蕨属 Ctenitis & 4 & 1.56 & 40.00 & 0.44 \\
\hline 水龙骨属 Polypodiodes & 4 & 4.55 & 30.77 & 0.44 \\
\hline
\end{tabular}


周喜乐, 张宪春, 孙久琼, 严岳鸿. 中国石松类和彍类植物的多样性与地理分布. 生物多样性, 2016, 24 (1), $102-107$. http://www.biodiversity-science.net/CN/10.17520/biods.2015256

\begin{tabular}{|c|c|c|c|c|}
\hline 属名 Genus & $\begin{array}{c}\text { 特有种 } \\
\text { Species endemic to } \\
\text { China (SEC) } \\
\end{array}$ & $\begin{array}{c}\text { 占科中特有种数比例 } \\
\text { Accounting for SEC in family } \\
(\%)\end{array}$ & $\begin{array}{c}\text { 占属中种数比例 } \\
\text { Accounting for species in } \\
\text { genus (\%) }\end{array}$ & $\begin{array}{c}\text { 占总特有种比例 } \\
\text { SEC in genus account- } \\
\text { ing for total SEC (\%) }\end{array}$ \\
\hline 薄唇葓属 Leptochilus & 3 & 3.41 & 17.65 & 0.33 \\
\hline 金粉蕨属 Onychium & 3 & 2.65 & 30.00 & 0.33 \\
\hline 金毛裸蕨属 Gymnopteris & 3 & 2.65 & 50.00 & 0.33 \\
\hline 轴果菜属 Rhachidosorus & 3 & 100.00 & 60.00 & 0.33 \\
\hline 伏石蕨属 Lemmaphyllum & 3 & 3.41 & 50.00 & 0.33 \\
\hline 瓶蕨属 Vandenboschia & 2 & 28.57 & 28.57 & 0.22 \\
\hline 瓶尔小草属 Ophioglossum & 2 & 100.00 & 22.22 & 0.22 \\
\hline 姬硕属 Hypolepis & 2 & 11.11 & 25.00 & 0.22 \\
\hline 碗葓属 Dennstaedtia & 2 & 11.11 & 22.22 & 0.22 \\
\hline 羽节蕨属 Gymnocarpium & 2 & 22.22 & 40.00 & 0.22 \\
\hline 圣濒属 Dictyocline & 2 & 1.87 & 50.00 & 0.22 \\
\hline 荚囊蕨属 Struthiopteris & 2 & 100.00 & 66.67 & 0.22 \\
\hline 节毛萨属 Lastreopsis & 2 & 28.57 & 66.67 & 0.22 \\
\hline 网藤葓属 Lomagramma & 2 & 0.78 & 100.00 & 0.22 \\
\hline 扇濒属 Neocheiropteris & 2 & 2.27 & 100.00 & 0.22 \\
\hline 滨禾蕨属 Oreogrammitis & 2 & 2.27 & 28.57 & 0.22 \\
\hline 辐禾蕨属 Radiogrammitis & 2 & 2.27 & 50.00 & 0.22 \\
\hline 盾蕨属 Neolepisorus & 1 & 1.14 & 20.00 & 0.11 \\
\hline 芒萁属 Dicranopteris & 1 & 20.00 & 16.67 & 0.11 \\
\hline 车前蕨属 Antrophyum & 1 & 0.88 & 11.11 & 0.11 \\
\hline 舌濒属 Elaphoglossum & 1 & 0.39 & 12.50 & 0.11 \\
\hline 紫其属 Osmunda & 1 & 100.00 & 14.29 & 0.11 \\
\hline 鳞始蕨属 Lindsaea & 1 & 100.00 & 7.69 & 0.11 \\
\hline 瘤足䯾属 Plagiogyria & 1 & 100.00 & 12.50 & 0.11 \\
\hline 杪椤属 Alsophila & 1 & 100.00 & 8.33 & 0.11 \\
\hline 曲轴蕨属 Paesia & 1 & 5.56 & 100.00 & 0.11 \\
\hline 书带萨属 Haplopteris & 1 & 0.88 & 7.14 & 0.11 \\
\hline 亮毛蒴属 Acystopteris & 1 & 11.11 & 33.33 & 0.11 \\
\hline 针毛蕨属 Macrothelypteris & 1 & 0.93 & 12.50 & 0.11 \\
\hline 卵果菜属 Phegopteris & 1 & 0.93 & 33.33 & 0.11 \\
\hline 边果蕨属 Craspedosorus & 1 & 0.93 & 100.00 & 0.11 \\
\hline 滇蕨属 Cheilanthopsis & 1 & 11.11 & 33.33 & 0.11 \\
\hline 荚果颜属 Matteuccia & 1 & 100.00 & 50.00 & 0.11 \\
\hline 符藤硕属 Teratophyllum & 1 & 0.39 & 100.00 & 0.11 \\
\hline 藤蕨属 Lomariopsis & 1 & 100.00 & 33.33 & 0.11 \\
\hline 肾蕨属 Nephrolepis & 1 & 100.00 & 16.67 & 0.11 \\
\hline 牙硕属 Pteridrys & 1 & 14.29 & 33.33 & 0.11 \\
\hline 假钻毛蕨属 Paradavallodes & 1 & 33.33 & 33.33 & 0.11 \\
\hline 小膜盖鄀属 Araiostegia & 1 & 33.33 & 25.00 & 0.11 \\
\hline 骨碎补属 Davallia & 1 & 33.33 & 16.67 & 0.11 \\
\hline 剑蕨属 Loxogramme & 1 & 1.14 & 8.33 & 0.11 \\
\hline 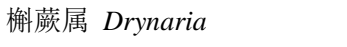 & 1 & 1.14 & 11.11 & 0.11 \\
\hline 拟水龙骨属 Polypodiastrum & 1 & 1.14 & 25.00 & 0.11 \\
\hline 瘤蕨属 Phymatosorus & 1 & 1.14 & 16.67 & 0.11 \\
\hline 星蕨属 Microsorum & 1 & 1.14 & 16.67 & 0.11 \\
\hline 爬树蕨属 Arthropteris & 1 & 100.00 & 50.00 & 0.11 \\
\hline 石松属 Lycopodium & 1 & 3.23 & 7.14 & 0.11 \\
\hline 针旱蕨属 Argyrochosma & 1 & 0.88 & 100 & 0.11 \\
\hline
\end{tabular}


周喜乐, 张宪春, 孙久琼, 严岳鸿. 中国石松类和蕨类植物的多样性与地理分布. 生物多样性, 2016, 24 (1), $102-107$.

http://www.biodiversity-science.net/CN/10.17520/biods.2015256

附录5 中国和世界植物热点地区的石松类和蕨类植物比较

Appendix 5 Comparison of lycophytes and ferns in China with plant hot regions in the world

\begin{tabular}{|c|c|c|}
\hline $\begin{array}{c}\text { 国家和地区 } \\
\text { Countries or regions }\end{array}$ & $\begin{array}{l}\text { 种数 } \\
\text { Species }\end{array}$ & $\begin{array}{l}\text { 参考文献 } \\
\text { Reference }\end{array}$ \\
\hline 中国 China & 2,270 & 本文 This article \\
\hline 哥伦比亚 Colombia & 1,410 & Hassler \& Swale, 2001 \\
\hline 厄瓜多尔 Ecuador & 1,318 & Hassler \& Swale, 2001 \\
\hline 巴西 Brazil & 1,309 & Hassler \& Swale, 2001 \\
\hline $\begin{array}{l}\text { 婆罗洲 Borneo (Sarawak, Sabah, Kalimantan, Brunei, including Natuna } \\
\text { islands, Riouw Arch.) }\end{array}$ & 1,185 & Hassler \& Swale, 2001 \\
\hline $\begin{array}{l}\text { 新几内亚 New Guinea (Irian Jaya and Papua New Guinea, including D'En- } \\
\text { trecasteaux islands, Louisiade archipelago, Rennell islands) }\end{array}$ & 1,183 & Hassler \& Swale, 2001 \\
\hline 委内瑞拉 Venezuela & 1,173 & Hassler \& Swale, 2001 \\
\hline 菲律宾 Philippines & 1,100 & Angeles \& Buot, 2012 \\
\hline 印度 India & 1,100 & Chandra, 2000 \\
\hline 秘鲁 Peru & 1,057 & Hassler \& Swale, 2001 \\
\hline 哥斯达黎加 Costa Rica & 1,021 & Hassler \& Swale, 2001 \\
\hline 墨西哥 Mexico (including Baja California, Guadalupe islands) & 999 & Hassler \& Swale, 2001 \\
\hline 巴拿马 Panama & 878 & Hassler \& Swale, 2001 \\
\hline 危地马拉 Guatemala & 674 & Hassler \& Swale, 2001 \\
\hline 马来半岛 Peninsular Malaysia & 660 & Hassler \& Swale, 2001 \\
\hline 泰国 Thailand & 652 & Hassler \& Swale, 2001 \\
\hline 日本 Japan & 630 & Iwatsuki, 1992 \\
\hline $\begin{array}{l}\text { 苏门答腊 Sumatra (including Mentawai, Enggano, Nias, Simeuleu, Lingga, } \\
\text { Anambas, Krakatau, Bangka, Belitung) }\end{array}$ & 615 & Hassler \& Swale, 2001 \\
\hline 越南 Vietnam & 591 & Hassler \& Swale, 2001 \\
\hline 牙买加 Jamaica & 549 & Hassler \& Swale, 2001 \\
\hline 爪哇 Java (including Madura island) & 519 & Hassler \& Swale, 2001 \\
\hline 古巴 Cuba & 495 & Hassler \& Swale, 2001 \\
\hline $\begin{array}{l}\text { 非洲南部 Southern Africa (Angola, Botswana, Lesotho, Malawi, Mozam- } \\
\text { bique, Namibia, South Africa) }\end{array}$ & 490 & Roux, 2001 \\
\hline 澳大利亚 Australia & 416 & Jones \& Clemesha, 1982 \\
\hline 北美 North America & 406 & Lellinger, 1985 \\
\hline 欧洲 Europe & 154 & Hassler \& Swale, 2001 \\
\hline
\end{tabular}

附录5 参考文献

Angeles M, Buot I (2012) Orders and families of Philippine pteridophytes. Journal of Nature Studies, 11(1-2), 19-33.

Chandra S (2000) The Ferns of India. International Book Distributors, Dehra Dun.

Hassler M, Swale B (2001) World Fern Statistics by Country. http://www.planta.cn/forum/files_planta/paragraphoe_635.pdf (accessed 2016-01-16)

Iwatsuki K (1992) Ferns and Fern Allies of Japan. Heibonsha Ltd. Publishers, Tokyo.

Jones DL, Clemesha SC (1981) Australian Ferns and Fern Allies, 2nd edn. A H \& A W Reed Pty Ltd., Wellington.

Lellinger DB (1985) Ferns and Fern Allies of the United States and Canada. Smithsonian Institution Press, Washington, D. C.

Roux JP (2001) Conspectus of Southern African Pteridophyta: An Enumeration of the Pteridophyta of Angola, Botswana, Lesotho, Malawi, Mozambique, Namibia, South Africa (including the Marion Island Group), Swaziland, Zambia and Zimbabwe. Sabonet, Pretoria. 